\title{
7 THE EFFECT OF BORDERS ON IDENTITY BUILDING IN MINORITY LIFE
}

\section{Enikö Molnár Bodrogi}

Babeş-Bolyai University, Romania, Email: mbeniko@gmail.com

\section{Acknowledgements}

This paper has been presented at the Ninth Annual International Conference on Baltic and Nordic Studies in Romania: 100 Years since Modern Independence and Unification in Baltic Sea Region and East-Central Europe held in Târgoviște, Romania, during November 15-16, 2018.

\begin{abstract}
:
In my research, I have used the postmodern concept of border to analyze the influence of borders on identity building of a national minority, namely that of the Hungarians in Transylvania in the interwar period. According to recent border studies, borders can be dealt with as zones and as cultural and mental landscapes, which serve to make contacts between different entities (in the case of this research between different linguistic and ethnic groups).

The aim of this study is to seek possible answers to questions such as why and how people produce borders through symbols and narratives. How does the human perception of a landscape influence the shaping of a landscape and the way people treat that landscape? In a narrower sense, it analyzes topics like the interpretation of national minority existence, the bidirectional attempt to construct and deconstruct virtual borders and the symbolic value of the mother tongue for a minority. The basic materials of my present study are Transylvanian Hungarian literary texts.

As far as the theoretical basis of the study is concerned, I analyze the topic from the perspective of border studies, cultural and mental landscape studies and identity studies.

\section{Rezumat:}

In acest studiu am folosit conceptul postmodern de frontieră pentru a analiza influența frontierelor asupra dezvoltării identități unei minorități naționale, în speță a maghiarilor din Transilvania în perioada interbelică. In conformitate cu studiile recente de limologie (border studies), frontierele pot fi abordate ca zone sau peisaje culturale și mentale, care fac legătura între entități diferite (în cazul de față, dintre diferite grupuri lingvistice și etnice).
\end{abstract}


Acest articol își propune să caute răspunsuri la următoarele întrebări: de ce și în ce fel construiesc oamenii frontiere folosind diferite simboluri și relatări? In ce fel influențează percepția umană a unui peisaj modelarea acestuia și modul în care oamenii îl tratează? În sens mai limitat, articolul analizează teme ca interpretarea existenței unei minorități naționale, încercarea bidirecțională de a construi și a deconstrui frontiere virtuale precum și valoarea simbolică a limbii materne pentru o minoritate. Articolul se bazează pe texte din literatura maghiară transilvăneană. Din punct de vedere teoretic, articolul are la bază studii de limologie, studii ale peisajului cultural și mental, precum și studii psihologice de identitate.

Keywords: Transylvanism; border; identity building; cultural and mental landscape

\section{"Border" as a Concept}

Borders can be considered the most palpable political and geographical phenomena ${ }^{1}$. From a geo-political point of view, a border is an imaginary line which hardly bears any information about the area it divides, about its history and culture. It is only a testimony of the region being divided and ignores historical differences, continuity and overlaps which, on the other hand, are quite important for the inhabitants who experience the practical existence of the frontier ${ }^{2}$.

Let us briefly see what exactly borders mean for the individuals. In a classical sense we may speak about natural and non-natural borders. From the beginning of the 20th century, this meaning was connected with another classical sense, namely good and bad ones. Although there were exceptions, generally the natural borders (e.g. mountain, sea, desert) were considered good borders and those drawn by people - bad, artificial ones ${ }^{3}$. These are, for instance, the state borders, language and cultural borders. As a result of all these, also psychological borders are formed, both at intrapersonal and interpersonal levels.

\footnotetext{
${ }^{1}$ Henk van Houtum, 'The Geopolitics of Borders and Boundaries.' Geopolitics 10 (2005): 672. Routledge. Taylor \& Francis Group. [ONLINE]: http://www.unice.fr/crookallcours/iup_geopoli/docs/geopoliticsborders2005.pdf, accessed on 8.11.2018.

2 Helena Ruotsala, 'Kaksi kukkaroa ja kaksi kelloa. Ylirajaisuutta ja monipaikkaisuutta Tornion - Haaparannan kaksoiskaupungissa.' Sananjalka 53 (2011): 202.

${ }^{3}$ Ibid.
} 
It is the way how borders were created and which stands at the center of today's border researches. That is, with the help of which symbols, signs, identifications, representations and narratives are borders created?

In this study, I do not only and not mainly use the concept of border in its meaning concerning territory. I rather use it with the meaning of a virtual territory through which communication can be achieved among groups of people, with social and space differences 5 . If we accept that borders are in fact the products of our knowledge and interpretation, as such, they will serve us as lenses to help us imagine and understand the world 6 .

So, it is only worth interpreting the borders as dynamic phenomena, social (and constructed) institutions, as well as symbols that are malleable and able to dynamically change. The borders (borders among groups of people, among languages and cultures, in our case) control the social sphere and we consider their construction - in agreement with Ruotsala - one of the ways to exercise power?

From an anthropological point of view, the border generally means the differences constructed in society and space between cultures, meaning also a demarcation line in space ${ }^{8}$. Along it, identity and group identities are formulated and the narratives serving their differentiating are of very different kinds.

\section{"Identity" as a Concept}

I consider it important - from the point of view of this study - to give a clear definition of "identity" as a concept. It is generally characteristic of narratives concerning identity to amply use metaphors. Let us mention expressions like "losing" or "searching" or "finding" identity. These words create the illusion that identity could be a palpable "thing", the object of the above-mentioned actions. Erik H. Erikson, one of the most influential identity researchers uses the metaphor rocky-bed in his work about Martin Luther's identity crisis and his finding a new identity 9 . He states that when somebody gets into identity crises, they need to sink as deeply as possible, to reach a safe ground, from where they are able to push themselves up to

\footnotetext{
4 van Houtum 2005: 675.

${ }^{5}$ Ibid. 672.

${ }^{6}$ Ibid. 674.

7 Ruotsala 2011: 202.

${ }^{8}$ van Houtum 2005: 672.

${ }^{9}$ Erik H. Erikson, A fiatal Luther és más írások. (Budapest: Gondolat, 1991).
} 
the surface and find who they really are. This means that in order to be able to find our own self, we need to go back to our ancient source. And many a time this road leads through the hell ${ }^{10}$. Psychologist Mérei Ferenc talks about the "labyrinth" of identity, which is the synonym of Erikson's "slough"11 in the sense that walking on the road leading to ourselves requires both effort and facing painful experience from the given individual.

In describing identity processes, it is worth keeping in mind Assmann's ascertainment that identity - being pluralia tantum - presumes the existence of further identities ${ }^{12}$. So, whenever we examine identity, we may take into consideration identity components like ethnic, linguistic, religious affiliations, political views, sex and age. They may have different intensities in each case and sometimes, depending on the given case, also their meaning can differ. Some of them are acquired at an early age, have deep roots in us and strong emotional feelings. Others change much more easily since they are more superficial.

In this study, I am going to use as operative definition the presumption which considers identity one of the most important premises of social life. According to it, personal ego is socially constructed from the very beginning, the individuals need to redefine themselves again and again and also others along their whole life. In order to define myself, I need to contrast myself with what I am not. And this is true both for individual and collective identities.

One of the key questions of the narrative concerning identity is just the determination of the differences among the different groups. This is a necessary venture, on the one hand, and a dangerous one, on the other. It is first of all necessary because the identity awareness of "us" can be created and known in relation with the "other". Difference also means power resource, since being conscious of the given group particularities gives a good basis for building one's identity and formulates the aims of the community, as well as determines the actions leading to their fulfillment. On

\footnotetext{
10 Ferenc Erős, Az identitás labirintusai. Narratív konstrukciók és identitás-stratégiák. (Budapest: Janus/Osiris, 2001), 13-14.

11 Ferenc Mérei, A pszichológiai labirintus. Fondorlatok és kerülőutak a lelki életben. (Budapest: Pszichoteam, 1989), 10.

12 Jan Assmann, A kulturális emlékezet. Írás, emlékezés és politikai identitás a korai magaskultúrákban. (Budapest: Atlantisz, 1999), 134.
} 
the other hand, there is danger in the fact that we may easily misjudge or deemphasize those people who are different from "us"13.

Summarizing all these, I interpret identity as such a dynamic phenomenon that changes under the influence of different objective or subjective influences or, putting it in other words, as constancy in the midst of perpetual change.

\section{Borders and Identities}

There are two quotations I'm starting this chapter of my article with. The author of one of them is K. Lengyel Zsolt, a Hungarian born in Transylvania, a political, social, and cultural historian, the other one's author is Anne Heith, a Swedish cultural and media researcher at the Umeå University. Both of them have accomplished a significant research work on the minority theme.

I have specifically chosen these two texts because they resume in a nutshell the basic issues concerning the relation between the ethnic majority and minorities living on bordering geographical territories. Cooperation between the different groups is not always easy, as the following quotation states:

"People frequently crossing borders need to compromise. They live at the bounds of territories jutting into one another, where different national communities live, and they have deeper roots in one culture than in the other. They know, out of their own experience, that a rational cooperation between individuals and groups of different origin depends on the mutual concession of those politically in charge. Such an inter-ethnic agreement is never perfect, as it only comes into being and lasts, if the protagonists keep decreasing in a balanced and indefatigable way their real or suspected demands."14

\footnotetext{
13 Sari Pietikäinen, Hannele Dufva, Sirkka Laihiala-Kankainen, “Kieli, kulttuuri ja identiteetti - ääniä Suomenniemeltä". in Moniääninen Suomi. Kieli, kulttuuri ja identiteetti, ed. Sirkka Laihiala-Kankainen-Sari Pietikäinen-Hannele Dufva (Jyväskylä: Jyväskylän yliopisto. Soveltavan kielentutkimuksen keskus, 2002), 16-17.

14 Zsolt K. Lengyel, “Az alternatívától a kompromisszumig. Pillanatkép a 20. század eleji politikai erdélyiség hangulatvilágáról”, in, A kompromisszum keresése. Tanulmányok a 20. századi transzszilvanizmus korai történetéhez, Zsolt K. Lengyel (Csíkszereda: Pro-Print Könyvkiadó, 2007), 5. [ONLINE]: http://adatbank.transindex.ro/html/alcim_pdf2899.pdf, accessed on 7.11.2018.
} 
The citation above speaks about the dynamic process of negotiating identities. It is just natural for an ethnic minority whose mother tongue is different from the majority's to have deeper roots in its own culture than in the culture of the other. On the other hand, identification with a culture different from the majority's does not exclude their loyalty to the country they are living in. Both groups have demands towards one another, but they both need to find a balance in negotiating their mutual relations.

According to Heith, cultural and political borders have often been in conflict:

\begin{abstract}
"Permeable and symbolic cultural borders have often been in conflict with borders constructed by the state in order to define its territory and the content of national culture and identity." 15
\end{abstract}

As opposed to the fiction of mono-lingual and mono-cultural state nation, historians differentiate the notions of ethnic nation (Kulturnation) and civic nation (Staatsnation). The former one means language, ethnic and cultural community, while the other means political formation built on public administration, legal system, armed forces, and the unity of the infrastructure ${ }^{16}$.

Minority life form is simply a given historical-social state, with no value in itself. On the other hand, as Cs. Gyímesi Éva points out, minority status offers value-creating possibilities as well. It offers the ethnicities living together the possibility of coining a fruitful connection from a moral and cultural point of view. Bi- or multilingualism of those living in such a situation, enriches the humanism of those who know one another's cultural heritage and literature ${ }^{17}$. In case of Transylvanian Hungarians self-reliance strengthened the need for linguistic and cultural independence.

\title{
Cultural and Mental Landscape
}

In his article about the relationship between landscape and literature in the $18^{\text {th }}$ century, Bending states that

\footnotetext{
15 Anne Heith, 'An Arctic Melting-Pot: the Byzantine Legacy and Bengt Pohjanen's Construction of a Tornedalian Aesthetic', Acta Borealia 1 (2010): 25.

16 László Cseresnyési, Nyelvek és stratégiák avagy a nyelv antropológája (Budapest: Tinta Könyvkiadó, 2004), 137.

17 Cs. Éva Gyímesi, Gyöngy és homok. Ideológiai értékjelképek az erdélyi magyar irodalomban (Bukarest: Kriterion Könyvkiadó, 1992), 29.
} 
"landscape is the co-modification of nature, that nature itself is always already a construct, that it is produced in contingent ways at different moments in cultural different societies" 18 .

Landscapes are thus created by a point of view, which is physical, ideological, intellectual and emotional ${ }^{19}$.

Landscape was defined in the $18^{\text {th }}$ century by the geographer, scientist and explorer Alexander von Humboldt as the "totality of all aspects of a region, as perceived by man" 20 . According to this, the defining element of the landscape is the human perception and the landscape is the sum of all aspects people can think of, natural, cultural, geographic, geologic, biologic, artistic etc. The human element, the way people think, has a key role in shaping, treating and reacting upon the landscape ${ }^{21}$. Without the human element, we cannot speak about landscape, only about (natural) environment.

Landscape, thus, is never something independent of the eye of the viewer, and it is focused on the viewer's sense of him/herself. What Bending tells about painted landscapes, namely that a landscape is never merely the record of what someone can see, but also an invitation to think about the act of seeing and the acts of judgment that this implies ${ }^{22}$, holds true also for literary landscapes.

In the context of this study, it is right to speak about the mental and cultural landscape Transylvanist writers present.

On the other hand, the point of view enables the viewer to construct landscape from the physical terrain, but, at the same time, allows the viewer to see beyond the physical limits of that terrain. Landscape is as much moral and political as it is visual and aesthetic ${ }^{23}$. Later on, I am going to examine how view point and eye movement are asserted in Transylvanist writers's works. A good example is Áprily's poem, Tetön (On Mountaintop), in which

18 Stephan Bending, "Literature and Landscape in the Eighteenth Century", 2, http://www.oxfordhandbooks.com/view/10.1093/oxfordhb/9780199935338.001.0001/oxf ordhb-9780199935338-e-133?print=pdf, accessed on 8.11.2018.

19 Ibid. 1.

${ }^{20}$ Quoted by Gerhard Ermischer, "Mental Landscape. Landscape as Idea and Concept", 2003. [ONLINE]: http://www.pcl-eu.de/project/agenda/mental.php, accessed on 21.09.2018.

21 Ibid.

22 Bending, 3.

${ }^{23}$ Ibid. 
the poet invites his audience to see besides the physical world, the moral and the metaphysical one, as well.

\section{Transylvanism}

Transylvanism has generally been viewed as the main regional ideology of the Transylvanian cultural and spiritual life in the interwar period. It was elaborated by Hungarian writers, historians and journalists in Romania immediately after 1919 . However, its roots can be traced back to the Hungarian national movement of the $19^{\text {th }}$ century.

This ideology aimed to reinforce the collective identity of the ethnic and linguistic minority of Hungarians in Romania. As some recent researches point out, Transylvanism (as regionalism) has not been exclusively a Hungarian brand. There were also Romanian and Saxon Transylvanists, forming their own groups and elaborating their own views upon Transylvania 24 .

In my article, I will focus on the main characteristics of the Transylvanist ideology as elaborated by the Hungarian intellectuals from Transylvania. The representatives of Transylvanism have not advocated a well-defined or systematic ideology. There are different variants of Transylvanism, which have implied contradictory thoughts. Transylvanism was a flexible idea, adjustable to the personal convictions of its representatives ${ }^{25}$. The main issue for them was the political selfdetermination as an ethnic-national entity in Romania.

Transylvanism has mainly been considered a political ideology, but the phenomenon is more than that. According to Láng26, it was meant to give answers to the questions raised by the identity crisis that Hungarians in Transylvania encountered in their new, minority situation. The only means of preserving their identity as a community was their own culture, based on

\footnotetext{
24 Zsuzsanna Török, "Transylvanism: A Politics of Wise Balance? Minority Regionalism in Interwar Romania. (1918-1940)", in Regionale Bewegungen und Regionalismen in europäischen Zwischenräumen seit der Mitte des 19. Jahrhunderts, ed. Philipp Ther and Holm Sundhaussen (Marburg: Verlag Herder-Institut, 2003), 128. [ONLINE]: https://www.herderinstitut.de/fileadmin/user_upload/pdf/vergriffene_Publikationen/Herder_Institut_Tagun gen_Band18.pdf, accessed on 19.03. 2016; Imola Katalin Nagy, 'Transylvanianism as Identity Discourse.' Acta Universitatis Sapientiae, Philologica, 3 (2014), 318. [ONLINE]: http://www.diacronia.ro/ro/indexing/details/A16880/pdf, accessed on 9.11.2018.

25 Béla Pomogáts, A transzilvánizmus. Az Erdélyi Helikon ideológiája (Budapest: Akadémiai Kiadó, 1983), 8.

${ }^{26}$ Gusztáv Láng, Kivándorló irodalom. Kísérletek (Kolozsvár: Korunk Baráti Társaság, 1998), 5.
} 
their mother tongue and their national traditions, all these adjusted to the new situation.

"Transylvanism was characterized by a strong regional note, linked to the democratic ideal of cultural pluralism." 27 According to this ideology Transylvania had a specific and particular spirituality which has been shaped throughout the centuries and was rooted in landscape, history, and cultural diversity. Tolerance towards otherness, differentness was considered to be the basic feature of this spirituality.

The core of Transylvanism lies in the fact that it postulates a certain historical predestination that all the nations (ethnic groups) in Transylvania could live together in peace and harmony and have equal rights.

The minority identity did not manifest itself as an ideology but rather as a collective feeling. The stability of the natural environment compensated for the fragile and unstable political status of the Hungarians in Transylvania.

\section{Symbols of Moral Values}

In the Hungarian literature of the time, Transylvanian nature appears as the bearer of moral values: those of steadiness, loyalty and invincibility (see the works of Tompa László, Reményik Sándor, Áprily Lajos, Dsida Jenő, Tamási Áron, Berde Mária, Kuncz Aladár). At the same time, Transylvanism was seeking the basis of national unity of Hungarians in cultural values and these values had a strong moral charge. A nation was, according to this concept, a moral community that manifested itself in its collective culture and demanded from all its members the assumption of a common mission. This messianism constituted one of the central themes of Hungarian literature in Transylvania.

\section{Messianism}

Kós Károly (1883-1977), a Hungarian architect, writer, ethnologist and politician, was the most notable advocate of the Transylvanist ideology. He and two contemporary intellectuals of the time, Zágoni István and Paál Árpád, wrote the first document on Transylvanism, a pamphlet entitled Kiáltó szó Erdély, Bánság, Körösvidék és Máramaros magyarságához!28 (Calling

\footnotetext{
27 Török, 128.

28 Kiáltó szó Erdély, Bánság, Körösvidék és Máramaros magyarságához! [ONLINE]: http://adatbank.transindex.ro/html/cim_pdf1374.pdf, accessed on 9.11.2018.
} 
Voice to the Hungarians in Transylvania, Banat, Crishana, and Maramures). Its motto is a quotation from the Bible, John 1: 21-23. These verses were translated in different ways into English, the result of different interpretations of the text. I focused on Verse 21, which includes the phrase: "I am the voice of one calling in the wilderness" / "I am a voice crying in the wilderness" / "I am the voice shouting in the wilderness" 29 . The difference between these translations reflects the fact that an ideology can be received in different ways by different people and groups. The "voice" of an ideologist can either be an echo-less cry or a call to which the audience answers, depending on the many historical and social circumstances which influence their lives.

The main feature of Transylvanism - which is the activism its representatives promoted - is embedded in the title of the pamphlet. The Transylvanists have striven to inspire the members of their communities to build a future for themselves.

“We have woken up. We want to see clearly. We want to face Life and be clear about our own situation. We want to know ourselves. We have to consider our forces, organize our work and we have to know the goal we want to achieve." 30

In this pamphlet and in his earlier work, such as the weekly review Kalotaszeg, Kós suggested that there had always existed a particular Transylvanian identity, which had sufficient self-definition and which might offer possibility for the Hungarians in Transylvania to raise this identity to the status of national identity in the context of an ethnic autonomy.

Another Transylvanist of the time, Dsida Jenó, combined in his poem Nagycsütörtök (Maundy Thursday) a religious topic (the suffering of Jesus in the Garden of Gethsemane) with the topic of the loneliness and spiritual distress of an individual belonging to the Hungarian community in Romania. The parallelism between Jesus and the member of an ethnic minority group is composed tangibly:

"it would have been so good to speak a little

to close friends, a few words to men you trust,

${ }^{29}$ Bible Hub, [ONLINE]: http:// biblehub.com/john/1-23.htm, accessed on 9.11.2018.
${ }^{30}$ Kiáltó szó..., 3. Transl. by Enikó Molnár Bodrogi. 
but there was only damp night, dark and chill, Peter was now asleep, and James and John asleep, and Matthew, all of them asleep..." 31 .

The ambiguity and the iterative passage between the concrete and the symbolic situation make the poem so rich in meaning.

Making virtue out of necessity was a common aim of the representatives of Transylvanism. To replace the negatively charged minority status with positive options that are true to Transylvanian values. Beginning with the 1920s, the symbol of the oyster (the pearl and sand) has become very common in Transylvanian Hungarian literature. It is the symbol of the "productive pain" caused to Hungarians by the change in their social status (becoming a national minority), a kind of moral answer to the historical and psychological shock they had experienced ${ }^{32}$. Thus, it is used as a moral symbol, involving a disharmony between a negative cause and a positive effect.

This perception is quite close to the Christian cult of suffering. It is not by mere chance that Christian references and intertexts are frequent in the interwar Transylvanian literature. In Tamási Áron's grotesque short story, Himnusz egy szamárral 33 (Hymn with a Donkey), two opposite systems of values crash, symbolizing two alternatives of a certain historical situation at any kind of border ${ }^{34}$. The protagonist of the text, Demeter Gábor, is in a double border situation. He arrives home from the war, full of hopes and immediately falls in a crisis in his private life (his wife has left him). He gives an irregular answer to his challenges: "I'll buy a donkey and start a new life" 35 . The village community has not recovered yet from the shock of social and political changes following the World War and they reject, even rule out as a collective individual the "prophet" who wants to lead his life according to his own notions. In the context of the short story, the donkey is the symbol

\footnotetext{
31 George Gömöri, 'Introduction to Jenő Dsida's Poems. Poems translated by George Gömöri and Clive Wilmer', Hungarian Review 4 (2013) [ONLINE]: http://www.hungarianreview.com/article/introduction_to_jeno_dsidas_poems_poems_tra nslated_by_george_gomori_and_clive_wilmer, accessed on 8.11.2018.

32 Cs. Gyímesi 1992, 10.

33 Áron Tamási, "Himnusz egy szamárral", in Tamási Áron válogatott novellái, 76-83. [ONLINE]: http://mek.oszk.hu/01000/01093/01093.pdf, accessed on 29.10.2018.

34 Cs. Éva Gyímesi, Teremtett világ. Rendhagyó bevezetés az irodalomba (Bukarest: Kriterion, 1983), 145.

35 Tamási, 78.
} 
of undemandingness and stubborn working, referring to the life of Jesus, at the same time.

The tiff between Demeter Gábor and the village community may also be interpreted as an ideological conflict: the protagonist offers solutions to undertaking minority life and urges his fellows to constructive action. At the same time, the others - not seeing any way out of their situation - receive his ideas scoffing at the beginning and with complete incomprehension and hostile feelings later on.

At the end of the short story, the protagonist is glorified in a grotesquely fantastic way. He is accused of murder and sentenced to leave the village on donkey-back. This is exactly the opposite of Christ's glorious entry to Jerusalem on Palm Sunday. Demeter Gábor mounts his donkey and it whirls away with him like a fairy-tale steed "towards the future" 36 .

The short-story finishes with a mythic turn, when the symbol of the archetypical Antichrist is evoked in the dumbstruck villagers.

'On that day, at dusk, four Sekler old men are talking on the road.

"That was no donkey at all, it must have been a huge rabbit." said one of them.

"And the mounted man was not DEMETER Gábor, as he died in the war."

"Who could that have been then?" - asked the third one.

"That surely was the Antichrist himself."'37

The theme of Reményik Sándor's poem Az ige (The Word) is the collectivity protecting role of the mother tongue and, as such, the language is canonized as holy. The poem is built on enhancement and it sounds on the voice of the prophet. In the first stanza, the poet compares the mother tongue with a sanctuary, with a catacomb. Then it is worded as a request:

"Everybody should speak Hungarian

As if in pray,

As if carrying gold, incense, myrrh." 38

\footnotetext{
36 Ibid. 82.

37 Ibid. 83.

38 Sándor Reményik, "Az ige", in Reményik Sándor összes versei [ONLINE]: http://mek.oszk.hu/01000/01052/html/vers0503.htm\#70, accessed on 29.10.2018. Transl. by Betty Léb.
} 
Nursing one's mother tongue means adoration and its professional users are ministers in the eyes of the poet and he also draws attention upon the seriousness and solemnity of their task.

In the forth and last stanza he uses a metaphor that leaves no doubt about the language holiness:

“Take care: language now is a holy grail.

You drink its wine: you drink the wine of life." 39

In the dimensions of the poem's world (and in society by transference) it is the mother tongue that determines a collectivity's outside borders which separate them of others, at the same time assuring life and future for those who cannot find a way out while in identity crisis.

\section{Natural Symbols of Steadiness}

When reading the landscape literature of the Transylvanian Hungarian writers between the two World Wars, we must pay attention to the strategies used by these writers in order to establish a relationship with an imagined reading public.

As I have also noted earlier, Transylvanism is based upon the idea that space can shape the spirit, and region is a particular outcome of its intercultural relations and diversity. For the Hungarian writers Transylvania is, besides a geographical and historical place, also a cultural concept.

Identification processes imply the construction of palpable and symbolic frontiers. Hungarians in Transylvania discuss the separation of the in-group and out-group in their literature, and the main distinctive feature of the in-group is the minority language on which the culture of the group is built on.

The hierarchy of values has also played an important role: the top value being the birthplace, then the homeland followed by the universal. Local values have been believed to enrich values at the homeland level, as well as those on the largest scale (universal). According to Transylvanism, minority literature is most closely linked to universal values through the topics it deals with. The "minority humanism" often mentioned by the Transylvanists is interpreted as protecting against becoming nationalist.

${ }^{39}$ Ibid. 
Let us see some examples for natural symbols of steadiness and harmony seeking.

In the poetry of Áprily Lajos mountains carry moral connotations and the mountaintop is a symbol of opposing opportunism, of preserving dignity ${ }^{40}$. The poem Tetön ${ }^{41}$ (On Mountaintop) is full of nature images and one can follow the drawing of borders between real and symbolic with the help of poetic means. At the same time, eye movement also structures scenery description. The border is placed between up and down, having the role of separating two value spheres. The poem is built on oppositions. The "down" describes the sphere of endangered, as well as missing values, using nature symbols such as autumn (season of passing) or the orphan foliage. Then, the poet opposes almost in every line the "down" (cauldron circling dark foliage, valley humming of fever) and the "up" (motionless old mountain, glare, mountaintop, white cheese, sheepfold, the eternal colors of the sky). He illustrates the disrupted harmony with the help of nature images, by contrasting life and the feeling of vulnerability, reality and the ideal, values and possibilities of their becoming real. The final echo of the poem is by all means positive: homeland, Transylvania carries immutability and harmony.

As we can see, the poem is also about the perpetuity of human values. Although life and reality on the one hand, and the circle of values on the other are far from each other, the looker-on has the ability to overcome previous chaos and to notice the connecting power of language and culture above political borders.

For Áprily, the peaceful coexistence of people speaking different languages and living on the same territory also belongs to permanence. An essential element of Transylvanism is that Romanians, Hungarians, and Saxons make peace, living in brotherhood and the mutual work done together for a mutual homeland means obligation for everybody. He thinks to find the bases of this harmonious life together in the people and in nature, rather than in Transylvanian history ${ }^{42}$.

\footnotetext{
40 Cs. Gyímesi 1983, 70.

41 Lajos Áprily, "Tetőn", in Áprily Lajos összes versei [ONLINE]: ftp:// ontologia.hu/Language/Hungarian/Crawl/MEK/mek.oszk.hu/00500/00592/00592.

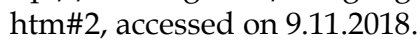

42 Zsigmond Vita, Áprily Lajos (Bukarest: Kriterion Könyvkiadó, 1972), 100.
} 
It is worth examining the key poem, $A z$ irisórai szarvas ${ }^{43}$ (The Deer of Irişoara), in which he also starts from a landscape. During one of his trips, he saw a fawn in the Mountains of Gilău. It had been bred up among domestic animals and the poet was inspired by its story. The poem is built upon that basic rule that the place of a wild-born being should not be in a cattle pen.

The fact that each line starts repetitively with "And it has forgotten..." (the brook, the spring) leads the reader back into the woods, into nature emphasizing more and more the antagonism between the origin and the current situation of the deer. The poem is an abstract expression of the conflict between identity and situation awareness with a person closed among barriers. The dramatic end: deer rutting sounding in the autumn is nothing but a human being's inertness and outcry for liberty. There is no possibility for real outbreak but the power of voice makes their unworthy existence culminate in a kind of catharsis. Unease and revolt sound in the poem, the pain of impotence and, at the same time, this pain gets melted into music.

The main characteristic of Tompa László's poetry is absence, the absence of the fulfillment of a free person's possibilities ${ }^{44}$. At the same time, one can find in it the most characteristic behavior of the interwar Hungarian writers: undertaking resistance. For instance, the rock fortress is a symbolic image synonym of the pearl oyster ${ }^{45}$. As with Áprily, "up" also stands for peace and safety, for the dimension where values are preserved, while "down" means unease and lack of values. A synonym image for the rock fortress is the solitary pine, growing on the barren headland, stubbornly sticking to the ground and defying wind and storm.

Winter landscape is also characteristic for Tompa, where houses and trees stoop under the snow and numbness relates the poet to his fellow citizens, whom he consciously shares fate with ${ }^{46}$.

Tompa takes suffering as one of his life tasks. In this situation awareness, the value of intellectual and artistic activity results rises high. As

43 Áprily, Lajos, "Az irisórai szarvas", in Áprily Lajos összes versei [ONLINE]: ftp:/ / ontologia.hu/Language/Hungarian/Crawl/MEK/mek.oszk.hu/00500/00592/00592. htm\#1, accessed on 9.11.2018.

44 Cs. Gyímesi 1992, 48.

45 László Tompa, "Sziklavár", in Tompa László válogatott versei [ONLINE]: http:/ / mek.oszk.hu/10300/10302/10302.htm\#1, accessed on 9.11.2018.

46 László Tompa, "Erdélyi télben", in Tompa László válogatott versei [ONLINE]: http:// mek.oszk.hu/10300/10302/10302.htm\#45, accessed on 9.11.2018. 
such, poetry means urge and comfort, able to make up for everything missing from real life. It is only poetry that is able to disengage in a cathartic way the conflicts of everyday ${ }^{47}$.

\title{
Constructing and De-constructing Borders
}

Human beings are always more than the outside aptness of their so called existence and it is a matter of individual decision the way they relate to a negative situation they got into. I am going to prove with an example how much self-consciousness depends on inside urge, namely with Molter Károly's title character of his novel Tibold Márton.

Cs. Gyímesi says that Tibold Márton is a typically East-European novel, as it bears a message valid from decades before the fall of the AustroHungarian Monarchy until nowadays. It is an example of moral and spiritual behavior of the ones who are able to get above antagonisms and assume even the tragic consequences of the situation, if necessary ${ }^{48}$.

\begin{abstract}
"However, TIBOLD Márton is much more than that. It means sensitiveness as far as identity and otherness, as well as national impatience and tolerance are concerned. It is the novel of EasternEurope. Because there is no other area in Europe, where the necessity of respect for otherness would be so great as here, where the ethnic and language differences begin not at the border, but practically at your neighbor's back garden or table or church." 49
\end{abstract}

The main character of the novel, Martin, is a Swabian child, born in a Serbian-Hungarian environment, in Bácska. He first experiences the disadvantage of being different from the point of view of a German, and at the end of the novel, from the point of view of a Hungarian. The Serbian landlord does not like Martin's father, as he is a friend of Hungarians. When Martin, still a child, wants to become a huszár (cavalryman), the landlord admonishes him: "You piggy Swabian, do you want to be Hungarian, as well? You will get Great Serbia instead." 50 By the end of the novel, as a teacher of German language, he mentions to one of his colleagues how useful it was for him to get the opportunity of studying in Jena. This had given him

\footnotetext{
47 Cs. Gyímesi 1992, 52.

48 Ibid. 35.

49 Ibid.

50 Károly Molter, Tibold Márton (Budapest: Révai, 1937), 6.
} 
a view towards the West. His colleague reacts nervously: "Come on now, little bro' TIBOLD, you are not going to mock German here at us." 51

Martin grows up and lives in a tolerant family environment. He learns Hungarian history from his German grandfather, who fought during the 1848 Revolution of Independence in defense of Hungary, against the Austrians.

"My ancestors have been living here for one and a half century. The
idea of captivity is alien to them; they had flown from revolutions and
oppression. Now they are rich and arrogant. They did not have any
opportunity to learn hating Hungarians who are poorer over here than
they are. A few roistering lordlings, the officials, some hicks or servile
new-Hungarians do not count. These Swabians have given their blood
for their new homeland. And I feel an exception even compared to
them, because I breathe together with the Hungarians." 52

The wish for self identity in case of Molter Károly's hero does not go hand in hand with suppressing or despising the other. "Romanian or Serbian? Better say Oláh or Rác. That's how they say it over here, scornfully..." "Well, those who say it. This narrowness is characteristic for every nation alike."'53

The right for self-identity and otherness is part of the human rights. It is Martin's own choice to learn and become Hungarian. He does not identify with the majority, much more with a minority he appreciates.

'“Are you Martin or Márton?" “Both. - It were really difficult to chose."
"After all, your mother delivered you as a German." "By no means. Just
as a human being. Who would become whatever he wanted to. She did
not talk me into being either German or Hungarian."'54

Even if Martin wants to become Hungarian he cherishes his mothertongue and would never deny it.

“"Do you forget your mother tongue here, in Kecskemét?" "Me? By no means. Only rascals or ill-fated persons would do that. I read German

\footnotetext{
51 Ibid. 121.

52 Ibid. 26.

53 Ibid. 68.

54 Ibid. 101.
} 
a lot. I am curious of a lot of things that can be read in this rich language. How beautiful German poems are and how much I love its poets!" "Do you love them as much as you love Hungarian poets?" "Exactly as much."'

Martin does not identify himself with a certain ethnicity in order to gain advantage, on the contrary he assumes even the biggest inconveniences to remain loyal to his decision.

Tibold Márton brings examples of the fact that in a multi-national surrounding, people are naturally open to values, irrespective of their language and cultural references. An inevitable approach of the different languages and cultures takes place, even if they do not merge.

In Molter Károly's novel, tolerance is not only characteristic for Transylvania, but also for East-Europe, in a larger sense ${ }^{55}$.

\section{Conclusions}

In my research I sought answers to questions like why and how people produce borders through symbols and narratives. How does human perception of a landscape influence the shaping of a landscape? I also analyzed topics like the interpretation of national minority existence, the attempt to construct and deconstruct virtual borders and the symbolic value of one's minority mother tongue in the context of other languages.

The main conclusions of this study are the following:

1. If we accept identity as constancy in the midst of perpetual change, it is just natural that after World War I the Hungarian community in Transylvania sought to reinforce their collective identity as a minority in their new political situation. One of the key questions in this process was to determine the differences among the different groups living on the same territory.

2. As the political status of Hungarians in Romania proved to be unstable, the stability of the natural environment compensated for it. The top value was considered to be the birthplace, then the homeland followed by the universal. Local values have been believed to enrich values at homeland level as well as at the largest scale (universal).

3. The literary texts I have analyzed reflect an ideology according to which place can form the spirit and the region where people speak the same

55 Cs. Gyímesi 1992, 38. 
language is a historical unit with its own culture, consciousness and pride. According to this ideology Transylvania had a specific and particular spirituality which has been shaped throughout the centuries and was rooted in landscape, history and cultural diversity. Tolerance towards otherness was considered to be the basic feature of this spirituality.

4. Transylvanian landscape was one of its inhabitants' main markers. Transylvanian nature also appears as bearer of moral values: those of steadiness, loyalty and invincibility.

5. A common aim of the representatives of Transylvanism was making virtue out of necessity. The idea of messianism and sacrifice has an important role in this ideology.

6. Besides landscape, the community's own culture, based on their mother tongue was considered to be a key element in preserving their identity. Hungarians in Transylvania appear in the literary texts as a moral community that manifested itself in its collective culture and demanded from all its members the assumption of a common mission.

Borders as cultural and mental landscapes are flexible and can be transgressed, on the one hand. But on the other hand, they might be stable when it comes to the basic characteristics of a certain community. 


\section{References:}

Áprily

Lajos

összes

versei.

$\mathrm{ftp}: / /$ ontologia.hu/Language/Hungarian/Crawl/MEK/mek.oszk. $\mathrm{hu} / 00500 / 00592 / 00592 . h t m$, accessed on 9.11.2018.

Assmann, Jan. A kulturális emlékezet. Írás, emlékezés és politikai identitás a korai magaskultúrákban. Budapest: Atlantisz, 1999.

Bending, Stephan. "Literature and Landscape in the Eighteenth Century", http:/ / www.oxfordhandbooks.com/view/10.1093/oxfordhb/9780 199935338.001.0001/oxfordhb-9780199935338-e-133?print=pdf, accessed on 8.11. 2018.

Bible Hub. http:/ / biblehub.com/john/1-23.htm, accessed on 9.11.2018.

Cs. Gyímesi Éva. Teremtett világ. Rendhagyó bevezetés az irodalomba. Bukarest: Kriterion, 1983.

Cs. Gyímesi, Éva. Gyöngy és homok. Ideológiai értékjelképek az erdélyi magyar irodalomban. Bukarest: Kriterion Könyvkiadó, 1992.

Cseresnyési, László. Nyelvek és stratégiák avagy a nyelv antropológája. Budapest: Tinta Könyvkiadó, 2004.

Erikson, Erik H. A fiatal Luther és más írások. Budapest: Gondolat, 1991.

Ermischer, Gerhard. "Mental Landscape. Landscape as Idea and Concept", 2003. http://www.pcl-eu.de/project/agenda/mental.php, accessed on 21.09.2018.

Erős, Ferenc. Az identitás labirintusai. Narratív konstrukciók és identitásstratégiák. Budapest: Janus/Osiris, 2001.

Heith, Anne. 'An Arctic Melting-Pot: the Byzantine Legacy and Bengt Pohjanen's Construction of a Tornedalian Aesthetic.' Acta Borealia 1 (2010): 24-43.

van Houtum, Henk, 'The Geopolitics of Borders and Boundaries.' Geopolitics 10 (2005): 672-679. Routledge. Taylor \& Francis Group. [ONLINE]: http://www.unice.fr/crookallcours/iup_geopoli/docs/geopoliticsborders2005.pdf, accessed on 8.11.2018.

K. Lengyel, Zsolt. 'Az alternatívától a kompromisszumig. Pillanatkép a 20. század eleji politikai erdélyiség hangulatvilágáról'. In $A$ kompromisszum keresése. Tanulmányok a 20. századi transzszilvanizmus korai történetéhez. K. Lengyel Zsolt. Csíkszereda: Pro-Print 
Könyvkiadó, 2007, 5-6. [ONLINE]: http://adatbank.transindex.ro/html/alcim_pdf2899.pdf, accessed on 7.11.2018.

Kiáltó szó Erdély, Bánság, Kőrösvidék és Máramaros magyarságához! [ONLINE]: http://adatbank.transindex.ro/html/cim_pdf1374.pdf, accessed on 9.11.2018.

Mérei, Ferenc. A pszichológiai labirintus. Fondorlatok és kerülőutak a lelki életben. Budapest: Pszichoteam, 1989.

Molter, Károly. Tibold Márton. Budapest: Révai, 1937.

Nagy, Imola Katalin, 'Transylvanianism as Identity Discourse.' Acta Universitatis Sapientiae, Philologica, 3 (2014): 317-333. [ONLINE]: http://www.diacronia.ro/ro/indexing/details/A16880/pdf, accessed on 9.11.2018.

Pietikäinen, Sari - Dufva, Hannele - Laihiala-Kankainen, Sirkka. 'Kieli, kulttuuri ja identiteetti - ääniä Suomenniemeltä'. In Moniääninen Suomi. Kieli, kulttuuri ja identiteetti. Ed. Sirkka Laihiala-Kankainen Sari Pietikäinen - Hannele Dufva. Jyväskylä: Jyväskylän yliopisto. Soveltavan kielentutkimuksen keskus, 2002, 16-17.

Reményik Sándor összes versei. http:/ / mek.oszk.hu/01000/01052/html/vers0503.htm\#70, accessed on 29.10.2018.

Ruotsala, Helena. 'Kaksi kukkaroa ja kaksi kelloa. Ylirajaisuutta ja monipaikkaisuutta Tornion - Haaparannan kaksoiskaupungissa.' Sananjalka 53 (2011): 202-205.

Tamási, Áron. 'Himnusz egy szamárral'. In Tamási Áron válogatott novellái, 76-83. [ONLINE]: http:// mek.oszk.hu/01000/01093/01093.pdf, accessed on 29.10.2018.
Tompa László válogatott versei.
http://mek.oszk.hu/10300/10302/10302.htm\#45, accessed on 9.11.2018.

Török, Zsuzsanna. 'Transylvanism: A Politics of Wise Balance? Minority Regionalism in Interwar Romania. (1918-1940)'. In Regionale Bewegungen und Regionalismen in europäischen Zwischenräumen seit der Mitte des 19. Jahrhunderts Ed. Philipp Ther and Holm Sundhaussen Marburg: Verlag Herder-Institut, 2003, 127-144. [ONLINE]: https://www.herder- 
42 | Revista Română de Studii Baltice şi Nordice / The Romanian Journal for Baltic and Nordic Studies 10 (1)

institut.de/fileadmin/user_upload/pdf/vergriffene_Publikationen /Herder_Institut_Tagungen_Band18.pdf, accessed on 19.03. 2016.

Vita, Zsigmond. Áprily Lajos. Bukarest: Kriterion Könyvkiadó. 1972. 